\title{
Evaluation of yellow lupine plant infection by fungal pathogens in different regions of Poland
}

\author{
Ocena porażenia roślin łubinu żółtego w różnych rejonach Polski \\ przez patogeny grzybowe
}

\author{
Janusz Podleśny, Anna Podleśna
}

\section{Summary}

The experiments were conducted during 2010-2012 at the Experimental Stations of The Research Centre for Cultivar Testing. The following yellow lupine cultivars were included in the studies: Baryt, Dukat, Lord, Mister, Parys, Perkoz, Talar and Taper. The occurrence of yellow lupine diseases such as anthracnose, root rots, leaf-spot, Fusarium wilt and Sclerotinia stem rot was evaluated. The aim of the study was the evaluation of infection degree of yellow lupine plants by fungal diseases in dependence on cultivar and the course of weather conditions in particular regions of Poland. In all the years of studies, the plant infection by pathogenic fungi was not too large and in greater intensity occurred only in some locations. Anthracnose and Fusarium dominated among identified lupine diseases occurred in regions of Poland with high amount of precipitations and temperature during lupine blooming stage. Among evaluated yellow lupine cultivars only some showed definitely greater resistance to all analyzed fungal diseases. The lupine cultivar Mister was infected at lower degree by fungal pathogens, especially in compare to the cultivar Paris. The results revealed great differences in the yellow lupine yielding between regions of its cultivation. However, in the most regions of Poland the highest yields gave the yellow lupine cultivar Baryt, while the lowest - the cultivar Parys.

Key words: yellow lupine; cultivar; pathogens; regions of Poland; yielding

\section{Streszczenie}

Doświadczenia prowadzono w latach 2010-2012 w Stacjach Oceny Odmian Centralnego Ośrodka Badania Odmian Roślin Uprawnych (COBORU). W badaniach uwzględniono odmiany łubinu żółtego: Baryt, Dukat, Lord, Mister, Parys, Perkoz, Talar i Taper. Określano występowanie chorób łubinu żółtego: antraknoza, zgorzel siewek, brunatna plamistość liści, fuzaryjne więdnięcie łubinu, zgnilizna twardzikowa. Celem badań była ocena stopnia porażenia łubinu żółtego przez patogeny grzybowe w zależności od odmiany oraz przebiegu warunków pogodowych w poszczególnych rejonach Polski. We wszystkich latach doświadczeń porażenie roślin przez grzyby chorobotwórcze nie było zbyt duże i w większym nasileniu występowało tylko w niektórych miejscowościach. Spośród stwierdzonych chorób łubinu dominowała antraknoza i fuzaryjne więdnięcie łubinu występujące w rejonach Polski z dużą ilością opadów i wysoką temperaturą w okresie kwitnienia łubinu. W obrębie uwzględnionych w badaniach odmian łubinu żółtego nie było zbyt dużo odmian wyróżniających się zdecydowanie większą odpornością na wszystkie analizowane grzyby chorobotwórcze. Jedynie odmiana Mister była nieco mniej porażana przez patogeny chorobotwórcze, zwłaszcza w porównaniu do odmiany Parys, która była najsilniej porażana. Stwierdzono duże różnice w plonowaniu łubinu żółtego pomiędzy rejonami jego uprawy. W większości rejonów Polski na ogół najlepiej plonował łubin odmiany Baryt, a najsłabiej - odmiana Parys.

Słowa kluczowe: łubin żółty; odmiana; patogeny; regiony Polski; plonowanie

Instytut Uprawy Nawożenia i Gleboznawstwa - Państwowy Instytut Badawczy

Czartoryskich 8, 24-100 Puławy

jp@iung.pulawy.pl 


\section{Wstęp / Introduction}

W ostatnich latach bardzo dynamicznie wzrasta powierzchnia uprawy łubinu, w tym głównie łubinu wąskolistnego i żółtego (Osiecka i Wiatr 2010). W dużej mierze wynika to z wprowadzonych w 2010 roku dopłat do uprawy roślin motylkowatych. Ponadto wielu rolników, zwłaszcza w gospodarstwach o mniejszej powierzchni użytków rolnych, uwzględnia w zmianowaniu łubin jako dobry przedplon dla wielu roślin, w szczególności zbóż (Dubis i Budzyński 1998). Dodatkowo łubin pozostawia znaczne ilości azotu w glebie, co pozwala na zastosowanie mniejszej dawki azotu stosowanego w uprawie rośliny następczej (Prusiński i wsp. 2008). Obok licznych zalet wynikających z uprawy łubinu, wadą jego są stosunkowo niskie i zmienne $\mathrm{w}$ latach plony nasion (Domański i wsp. 2013), co wynika w dużej mierze z przebiegu warunków pogodowych (Podleśny i Podleśna 2011, 2012), zwłaszcza niedoboru wody w glebie (Podleśny 2003) oraz porażenia roślin przez patogeny chorobotwórcze (Jasińska i Kotecki 1993). Szczególnie niebezpieczną chorobą jest antraknoza, która rozprzestrzenia się bardzo szybko w łanie (Filoda i wsp. 2001) i w skrajnym przypadku powoduje zniszczenie całej plantacji łubinu. Rozwój i przebieg tej choroby w bardzo dużym stopniu zależy od temperatury i wilgotności powietrza (Jańczak 2003), stąd obok śledzenia przebiegu pogody, zalecany jest także monitoring plantacji. Ponadto poszczególne gatunki łubinu charakteryzują się zróżnicowaną podatnością na porażanie przez sprawców chorób (Horoszkiewicz i Filoda 2001). W związku ze zróżnicowanymi warunkami klimatycznymi występującymi na obszarze Polski, ważnym zagadnieniem staje się określenie stopnia podatności odmian łubinu żółtego na porażenie przez patogeny grzybowe w różnych rejonach kraju. W przypadku wystąpienia takich zależności możliwe będzie dopasowanie wybranych odmian do poszczególnych rejonów ich uprawy. Przeprowadzona analiza umożliwi ponadto określenie wpływu przebiegu pogody na rozwój chorób i plonowanie łubinu żółtego.

W hipotezie badawczej zakładano, że porażenie roślin łubinu żółtego przez grzyby chorobotwórcze będzie zależało od odmiany i rejonu uprawy.

Celem badań była ocena stopnia porażenia roślin łubinu żółtego przez patogeny chorobotwórcze w zależności od odmiany oraz przebiegu warunków pogodowych w poszczególnych rejonach Polski.

\section{Materiały i metody / Materials and methods}

Doświadczenia prowadzono w latach 2010-2012 w Stacjach Oceny Odmian Centralnego Ośrodka Badania Odmian Roślin Uprawnych (COBORU), w następujących województwach: zachodniopomorskie (Białogard), wielkopolskie (Bobrowniki, Nowa Wieś Ujska), lubelskie (Cicibór Duży, Uhnin), kujawsko-pomorskie (Głodowo), podlaskie (Marianowo), podkarpackie (Nowy Lubliniec), warmińsko-mazurskie (Ruska Wieś), łódzkie (Sulejów), lubuskie (Świebodzin) i dolnośląskie (Tomaszów Bolesławiecki), w układzie losowanych bloków, w 4 powtórzeniach. W badaniach uwzględniono następujące odmiany łubinu żółtego: Baryt, Dukat, Lord, Mister, Parys, Perkoz, Talar i Taper. Odmiany te znajdowały się na Liście Odmian Roślin Rolniczych oraz wchodziły w skład wzorca służącego do oceny odmian w badaniach COBORU. Planowana obsada roślin była taka sama dla każdej miejscowości i wynosiła dla odmian: Parys, Mister, Dukat, Lord, Talar i Baryt - 90 roślin $/ \mathrm{m}^{2}$, a dla odmian: Taper i Perkoz - 120 roślin $/ \mathrm{m}^{2}$. Przedplonem były zboża. Nawożenia azotowego nie stosowano, natomiast wielkość dawek fosforu i potasu ustalono na podstawie analizy gleby. Przeciętne nawożenie wynosiło: $\mathrm{P}_{2} \mathrm{O}_{5}-40$ i $\mathrm{K}_{2} \mathrm{O}-$ $70 \mathrm{~kg} / \mathrm{ha}$. Siew wykonywano w końcu marca lub na początku kwietnia. W ciągu całego okresu wegetacji prowadzono szczegółowe obserwacje wzrostu i rozwoju roślin. W okresie kwitnienia łubinu określono podatność poszczególnych odmian łubinu żółtego na następujące choroby grzybowe: antraknoza (Colletotrichum gloeosporioides), zgorzel siewek (Rhizoctonia solani), brunatna plamistość liści (Pleiocheta setosa), fuzaryjne więdnięcie łubinu (Fusarium oxysporum) i zgnilizna twardzikowa (Sclerotinia sclerotiorum) poprzez ustalenie liczby roślin zdrowych i uszkodzonych przez patogeny na jednostce powierzchni. Za porażenie roślin przyjęto stosunek liczby roślin porażonych do łącznej liczby roślin wyrażony w \%.

Przebieg warunków pogodowych scharakteryzowano na podstawie ilości opadów i średniej dobowej temperatury powietrza. Powierzchnia poletek do zbioru wynosiła $16 \mathrm{~m}^{2}$. Po zbiorze określono plon nasion łubinu żółtego uzyskany w poszczególnych miejscowościach. W roku 2010, łubin żółty uprawiany był na glebach kompleksu żytniego bardzo dobrego i żytniego dobrego, natomiast w latach 2011 i 2012 na glebach kompleksu pszennego dobrego, żytniego bardzo dobrego i żytniego dobrego. Zwalczanie chwastów dwuliściennych prowadzono metodą chemiczną stosując najczęściej: Afalon Dyspersyjny $450 \mathrm{SC}$ (s.cz. linuron) w dawce 1,5-2,0 1/ha, Command 480 EC (s.cz. chlomazon) w dawce 0,2 1/ha lub Linurex 500 SC (s.cz. linuron) w dawce 1,0-1,5 1/ha. Chwasty jednoliścienne zwalczano stosując preparat Fusilade Super 125 EC (s.cz. fluazyfop-P-butylowy) w dawce 2,5 1/ha. Szkodniki zwalczano stosując najczęściej Karate Zeon 050 CS (s.cz. lambda-cyhalotryna) w dawce 0,15 1/ha lub Decis 2,5 EC (s.cz. deltametryna) w dawce 0,3 1/ha. Przeciw antraknozie stosowano fungicydy: Amistar 250 SC (s.cz. azoksystrobina) w dawce 1 1/ha lub Gwarant 500 SC (s.cz. chlorotalonil) w dawce 2 1/ha.

Przebieg warunków pogodowych w poszczególnych rejonach kraju był bardzo zróżnicowany (tab. 1) i różnie oddziaływał na: wzrost, rozwój i plonowanie łubinu żółtego. W roku 2010 stwierdzono duży niedobór opadów w kwietniu w miejscowościach Białogard i Uhnin, natomiast w maju w miejscowościach Świebodzin i Tomaszów Bolesławiecki oraz bardzo dużą ilość opadów w miejscowości Nowy Lubliniec. W czerwcu odnotowano duży niedobór opadów w miejscowości Bobrowniki i znaczny ich niedobór w miejscowościach Nowa Wieś Ujska i Głodowo. Przebieg warunków pogodowych w roku 2011 charakteryzował się mniejszą ilością opadów w okresie wegetacji łubinu w porównaniu do roku 2010, a zwłaszcza do roku 2012. Stwierdzono również bardzo nierówno- 
mierny rozkład opadów, dlatego w wielu miejscowościach w okresie wegetacji łubinu występował niedobór lub znaczny nadmiar opadów, na przykład ilość opadów w miesiącu maju w kolejnych latach badań wynosiła odpowiednio: 114, 45 i $48 \mathrm{~mm}$. Szczególnie duży deficyt opadów w 2012 roku wystąpił w maju w miejscowościach:
Głodowo, Sulejów i Białogard oraz w lipcu w miejscowości Cicibór Duży. Średnie temperatury dobowe kształtowały się różnie w poszczególnych latach i rejonach uprawy łubinu. Przeciętna temperatura dobowa dla wszystkich miejscowości w okresie kwiecień-lipiec w roku 2011 wynosiła $14,8^{\circ} \mathrm{C}$, a w latach 2010 i 2012 odpowiednio 15,0

Tabela 1. Miesięczna suma opadów oraz średnie temperatury dobowe dla poszczególnych miejscowości (2010-2012)

Table 1. Monthly sum of precipitation and mean day temperatures for individual locations (2010-2012)

\begin{tabular}{|c|c|c|c|c|c|c|c|c|}
\hline \multirow{2}{*}{$\begin{array}{c}\text { Miejscowość } \\
\text { Location }\end{array}$} & \multicolumn{4}{|c|}{ Opady - Precipitation [mm] } & \multicolumn{4}{|c|}{ Temperatura - Temperature $\left[{ }^{\circ} \mathrm{C}\right]$} \\
\hline & IV & $\mathrm{V}$ & VI & VII & IV & $\mathrm{V}$ & VI & VII \\
\hline \multicolumn{9}{|c|}{2010} \\
\hline Białogard & 11,7 & 95,6 & 58,3 & 114,7 & 7,3 & 10,1 & 15,6 & 20,6 \\
\hline Bobrowniki & 37,3 & 83,1 & 12,5 & 95,6 & 7,9 & 11,2 & 16,5 & 21,5 \\
\hline Cicibór Duży & 23,0 & 126,8 & 67,7 & 48,2 & 8,7 & 14,5 & 17,9 & 21,6 \\
\hline Głodowo & 29,2 & 143,3 & 44,7 & 130,7 & 8,5 & 12,5 & 16,8 & 21,4 \\
\hline Marianowo & 34,8 & 151,8 & 75,5 & 108,1 & 8,3 & 13,4 & 16,9 & 21,1 \\
\hline Nowa Wieś Ujska & 30,5 & 150,4 & 36,2 & 112,4 & 7,9 & 15,0 & 17,8 & 21,8 \\
\hline Nowy Lubliniec & 27,2 & 195,1 & 98,4 & 167,3 & 9,3 & 14,8 & 17,7 & 21,9 \\
\hline Ruska Wieś & 42,8 & 140,1 & 125,9 & 94,9 & 7,0 & 14,8 & 18,1 & 21,7 \\
\hline Sulejów & 25,7 & 148,9 & 58,3 & 86,7 & 8,3 & 12,4 & 16,9 & 20,6 \\
\hline Świebodzin & 53,8 & 24,3 & 128,3 & 111,7 & 7,9 & 13,8 & 15,0 & 18,4 \\
\hline Tomaszów Bolesławiecki & 53,8 & 24,3 & 128,3 & 111,7 & 7,9 & 13,8 & 15,0 & 18,4 \\
\hline Uhnin & 17,1 & 93,0 & 63,8 & 63,1 & 9,2 & 14,9 & 18,2 & 21,8 \\
\hline \multicolumn{9}{|c|}{2011} \\
\hline Białogard & 13,8 & 38,2 & 63,6 & 109,8 & 10,0 & 13,2 & 17,1 & 17,4 \\
\hline Bobrowniki & 5,0 & 32,7 & 65,2 & 152,2 & 10,4 & 14,0 & 18,3 & 17,8 \\
\hline Cicibór Duży & 37,6 & 61,2 & 65,4 & 201,6 & 9,6 & 13,8 & 18,4 & 18,7 \\
\hline Głodowo & 12,4 & 43,4 & 36,2 & 179,3 & 9,0 & 11,2 & 18,2 & 18,1 \\
\hline Marianowo & 38,7 & 58,0 & 58,3 & 273,9 & 9,6 & 13,4 & 17,7 & 18,5 \\
\hline Nowa Wieś Ujska & 8,1 & 44,1 & 48,1 & 174,4 & 10,8 & 13,9 & 18,0 & 17,6 \\
\hline Nowy Lubliniec & 52,2 & 31,2 & 86,9 & 201,5 & 11,0 & 14,1 & 18,4 & 19,2 \\
\hline Ruska Wieś & 35,7 & 67,1 & 43,9 & 191,6 & 9,8 & 14,6 & 18,1 & 18,4 \\
\hline Sulejów & 21,6 & 49,8 & 52,6 & 175,5 & 9,8 & 13,6 & 18,1 & 17,6 \\
\hline Świebodzin & 14,9 & 20,5 & 37,2 & 143,0 & 11,6 & 12,5 & 18,6 & 17,8 \\
\hline Tomaszów Bolesławiecki & 25,0 & 48,0 & 63,5 & 187,3 & 10,7 & 13,6 & 18,2 & 17,5 \\
\hline Uhnin & 39,9 & 46,2 & 116,3 & 169,7 & 9,6 & 14,0 & 18,4 & 18,7 \\
\hline \multicolumn{9}{|c|}{2012} \\
\hline Białogard & 31,6 & 24,7 & 104,2 & 102,2 & 8,0 & 13,7 & 15,6 & 18,2 \\
\hline Bobrowniki & 30,0 & 40,4 & 90,8 & 127,5 & 8,6 & 14,8 & 15,5 & 19,0 \\
\hline Cicibór Duży & 37,5 & 55,8 & 126,1 & 27,5 & 8,9 & 14,8 & 15,0 & 21,0 \\
\hline Głodowo & 34,9 & 17,9 & 124,4 & 89,7 & 9,1 & 15,4 & 16,1 & 20,9 \\
\hline Marianowo & 44,6 & 60,3 & 105,5 & 101,1 & 8,5 & 15,1 & 15,5 & 21,7 \\
\hline Nowa Wieś Ujska & 50,0 & 59,4 & 156,6 & 129,7 & 8,6 & 17,7 & 16,3 & 20,8 \\
\hline Nowy Lubliniec & 39,2 & 92,0 & 148,9 & 50,6 & 9,7 & 15,6 & 17,8 & 21,4 \\
\hline Ruska Wieś & 64,5 & 65,6 & 99,1 & 126,8 & 9,1 & 14,5 & 17,4 & 21,9 \\
\hline Sulejów & 41,5 & 22,7 & 69,0 & 60,3 & 8,8 & 14,7 & 16,0 & 20,5 \\
\hline Świebodzin & 32,6 & 54,8 & 79,3 & 154,4 & 9,4 & 15,5 & 15,5 & 19,3 \\
\hline Tomaszów Bolesławiecki & 45,5 & 45,8 & 74,8 & 118,1 & 8,5 & 14,4 & 16,1 & 18,8 \\
\hline Uhnin & 30,0 & 38,0 & 100,8 & 53,1 & 9,1 & 14,9 & 15,0 & 21,8 \\
\hline
\end{tabular}


i $15,2^{\circ} \mathrm{C}$. Stwierdzono natomiast większe zróżnicowanie średnich temperatur dobowych pomiędzy miejscowościami. W roku 2010 najniższą przeciętną temperaturę dobową $\mathrm{w}$ omawianym okresie stwierdzono w miejscowości Białogard $\left(13,4^{\circ} \mathrm{C}\right)$, a najwyższą w miejscowości Nowy Lubliniec $\left(15,9^{\circ} \mathrm{C}\right)$. W latach 2011 i 2012 najniższe temperatury odnotowano odpowiednio w miejscowościach: Głodowo $\left(14,1^{\circ} \mathrm{C}\right)$ i Białogard $\left(13,9^{\circ} \mathrm{C}\right)$, a najwyższe w miejscowości Nowy Lubliniec $\left(15,7 \mathrm{i} 16,1^{\circ} \mathrm{C}\right)$.

\section{Wyniki i dyskusja / Results and discussion}

W okresie wegetacji obserwowano zróżnicowane porażenie roślin przez grzyby chorobotwórcze w zależności od lokalizacji doświadczenia i lat badań oraz ocenianych odmian. We wszystkich latach badań stwierdzono występowanie następujących chorób łubinu żółtego: antraknoza, zgorzel siewek, brunatna plamistość liści, fuzaryjne więdniecie łubinu i zgnilizna twardzikowa, ale choroby te występowały w różnym nasileniu w czasie prowadzenia doświadczenia (rys. 1). We wszystkich latach badań w największym nasileniu występowały $C$. gloeosporioides i $F$. oxysporum czyli choroby, które są powszechnie uznawane za najgroźniejsze w uprawie łubinu żółtego (Podleśny i Brzóska 2010). W roku 2010 występowanie antraknozy było większe niż w pozostałych dwóch latach badań. Należy to wiązać $\mathrm{z}$ większą ilością opadów, bowiem zdaniem Filody i wsp. (2001), zwiększona ilość opadów sprzyja rozwojowi tej choroby. W roku 2011 stwierdzono, większe niż w pozostałych latach, nasilenie występowania fuzariozy, co wynikało z utrzymującej się w okresie wegetacji wyższej temperatury powietrza. Należy uznać, że spektrum chorób występujących w prowadzonych badaniach nie było zbyt duże, a według Horoszkiewicz i Filody (2001) łubin żółty może być jeszcze porażany przez wiele innych patogenów chorobotwórczych.

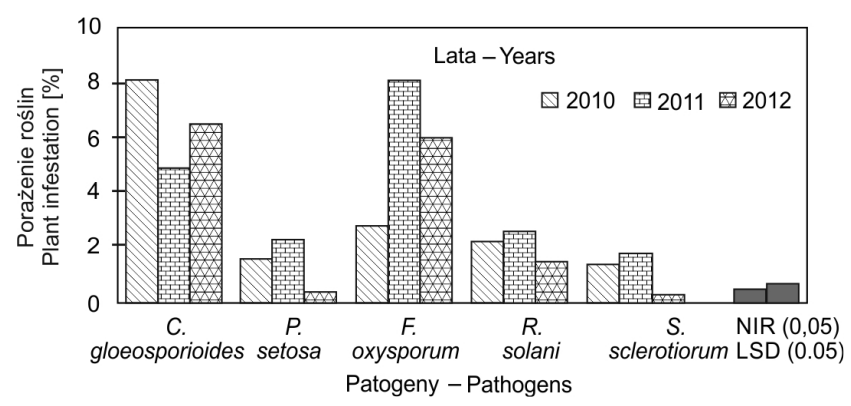

Rys. 1. Porażenie roślin łubinu przez patogeny grzybowe (średnia dla wszystkich miejscowości)

Fig. 1. Infection of yellow lupine plants by fungal pathogens (means for all locations)

Występowanie chorób grzybowych było bardzo różne w poszczególnych rejonach kraju (rys. 2). W największym stopniu rośliny grochu porażane były przez patogeny chorobotwórcze w miejscowościach: Cicibór Duży, Nowa Wieś Ujska, Nowy Lubliniec, Ruska Wieś i Sulejów. Należy również zaznaczyć, że chorobą najczęściej występującą, ale w różnym nasileniu w poszczególnych rejonach, była antraknoza (rys. 2). Największe porażenie roślin przez grzyba $C$. gloeosporioides powodującego tę chorobę wystąpiło w miejscowościach: Białogard, Cicibór Duży, Głodowo, Nowy Lubliniec i Ruska Wieś. Natomiast największe porażenie roślin łubinu żółtego przez $F$. oxysporum wystąpiło w miejscowościach: Nowa Wieś Ujska, Nowy Lubliniec i Sulejów.

Występowanie chorób grzybowych związane było przede wszystkim z korzystnym dla ich rozwoju przebiegiem warunków pogodowych: dla antraknozy - wysoka temperatura i duża ilość opadów, zwłaszcza w okresie kwitnienia (Frencel 1999), a dla fuzariozy - nadmierna wilgotność i niska temperatura (Sowa i Sadowski 1979) lub mała wilgotność i wysoka temperatura (Zalewski i wsp. 2003).

Z pozostałych chorób łubinu stwierdzono występowanie brunatnej plamistości liści w miejscowościach: Bobrowniki, Cicibór Duży, Nowa Wieś Ujska i Ruska Wieś, zgorzeli siewek w miejscowościach Cicibór Duży i Sulejów oraz zgnilizny twardzikowej w miejscowościach Cicibór Duży i Nowy Lubliniec.

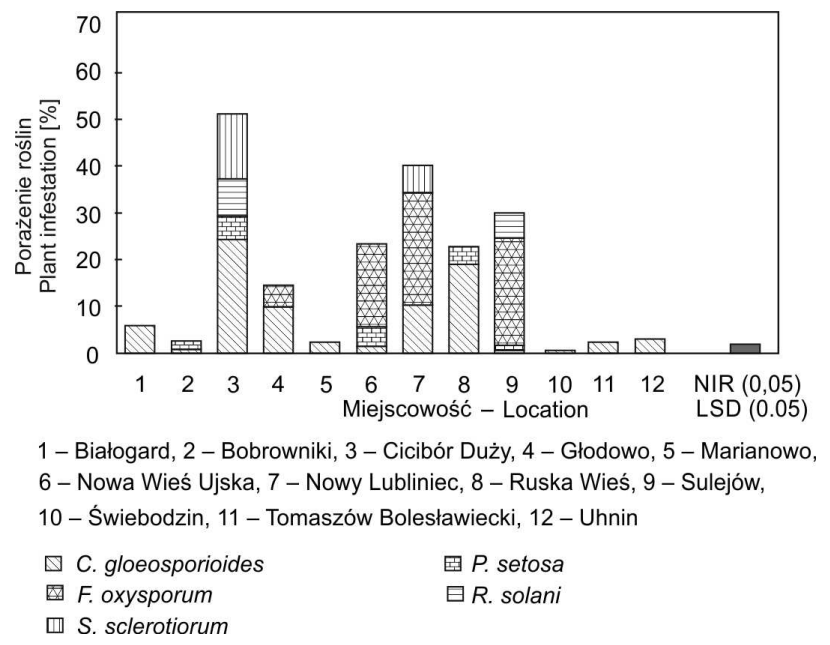

Rys. 2. Porażenie roślin łubinu przez patogeny grzybowe w zależności od rejonu Polski

Fig. 2. Infection of lupine plants by fungal pathogens in dependence on region of Poland

Na podstawie przeprowadzonej oceny można uznać, że różnica w odporności badanych odmian łubinu na antraknozę nie była zbyt duża (tab. 2), jedynie nieco większą odporność na tę chorobę stwierdzono w odniesieniu do odmian: Taper, Baryt, Mister i Perkoz, a zdecydowanie mniejszą - do odmiany Parys. W związku z tym, że odmiana Parys została wpisana na Listę Odmian Roślin Uprawnych w 1988 roku, a odmiana Taper w roku 2002, można przypuszczać, że obecnie w pracach hodowlanych zwraca się uwagę nie tylko na plon, lecz także na odporność odmian względem patogenów chorobotwórczych. Uzyskane wyniki nie znajdują potwierdzenia w badaniach Frencel (2000), w których wykazano, że występują duże różnice między odmianami $\mathrm{w}$ podatności na porażenie przez antraknozę. Jednak badania były prowadzone ze starszymi odmianami, których odporność na tę chorobę 
Tabela 2. Porażenie odmian łubinu żółtego przez patogeny grzybowe (2010-2012) [\%]

Table 2. Infection of yellow lupine cultivars by fungal pathogens (2010-2012) [\%]

\begin{tabular}{|c|c|c|c|c|c|}
\hline \multirow[b]{2}{*}{$\begin{array}{l}\text { Odmiana } \\
\text { Cultivar }\end{array}$} & \multicolumn{5}{|c|}{ Patogeny grzybowe - Fungal pathogens } \\
\hline & $\begin{array}{l}\text { antraknoza } \\
\text { C. gloeosporioides }\end{array}$ & $\begin{array}{c}\text { zgorzel } \\
\text { siewek } \\
R . \text { solani }\end{array}$ & $\begin{array}{c}\text { brunatna plamistość } \\
\text { liści } \\
\text { P. setosa }\end{array}$ & $\begin{array}{c}\text { fuzaryjne więdnięcie } \\
\text { łubinu } \\
\text { F. oxysporum }\end{array}$ & $\begin{array}{l}\text { zgnilizna twardzikowa } \\
\text { S. sclerotiorum }\end{array}$ \\
\hline Baryt & 7,8 & 11,1 & 12,2 & 90,0 & 15,5 \\
\hline Dukat & 10,0 & 12,2 & 7,8 & 71,1 & 17,8 \\
\hline Lord & 10,0 & 12,2 & 8,9 & 68,9 & 16,7 \\
\hline Mister & 7,8 & 12,2 & 8,9 & 55,5 & 18,9 \\
\hline Parys & 50,0 & 12,2 & 5,8 & 74,4 & 15,6 \\
\hline Perkoz & 7,8 & 16,7 & 8,9 & 71,1 & 17,8 \\
\hline Talar & 8,9 & 13,3 & 7,8 & 74,4 & 17,8 \\
\hline Taper & 6,7 & 15,5 & 8,9 & 73,3 & 18,9 \\
\hline Średnia - Mean & 13,6 & 13,2 & 8,6 & 72,3 & 17,4 \\
\hline $\begin{array}{l}\text { NIR }(0,05) \\
\operatorname{LSD}(0.05)\end{array}$ & 2,44 & 2,15 & 1,44 & 6,75 & 1,64 \\
\hline
\end{tabular}

mogła być inna niż odmian nowych, co wykazano częściowo również $\mathrm{w}$ prezentowanej pracy. Chorobą rzadko obserwowaną, nie występującą w ogóle w wielu miejscowościach, było fuzaryjne więdnięcie łubinu. Jednak w miejscowościach, gdzie stwierdzono jej występowanie, porażenie roślin przez $F$. oxysporum było bardzo duże. Bardzo wrażliwą na tę chorobę okazała się odmiana Baryt, a najmniej wrażliwą - odmiana Mister. Najogólniej należy stwierdzić, że w obrębie uwzględnionych w badaniach odmian łubinu żółtego nie ma zbyt dużo odmian, które wykazywałyby zdecydowanie większą od pozostałych odporność na wszystkie analizowane choroby grzybowe. Jedynie odmiana Mister była nieco mniej porażana przez patogeny chorobotwórcze, zwłaszcza w porównaniu do odmiany Parys.
Plonowanie łubinu żółtego było zróżnicowane w zależności od odmiany i rejonu uprawy (tab. 3). Średnio z 3 lat badań, najwyższy plon nasion łubinu żółtego uzyskano w miejscowości Bobrowniki, a najniższy w miejscowościach Nowy Lubliniec i Świebodzin. Nie stwierdzono wyraźnej zależności pomiędzy porażeniem roślin przez patogeny chorobotwórcze a ich plonowaniem. Wprawdzie łubin żółty plonował najwyżej w miejscowości Bobrowniki, gdzie stwierdzono bardzo małe porażenie roślin przez większość ocenianych patogenów chorobotwórczych, ale wysokie plony nasion tego gatunku uzyskano także w miejscowości Cicibór Duży, w której porażenie roślin przez patogeny grzybowe było największe. Bardzo niskie plony nasion łubinu uzyskano w miejscowości Świebodzin, gdzie występowanie analizowanych chorób

Tabela 3. Plonowanie łubinu żółtego w latach 2010-2012 [dt/ha] Table 3. Yielding of yellow lupine in the years $2010-2012$ [dt/ha]

\begin{tabular}{|c|c|c|c|c|c|c|c|c|c|c|c|c|c|}
\hline \multirow{2}{*}{$\begin{array}{l}\text { Odmiana } \\
\text { Cultivar }\end{array}$} & \multicolumn{12}{|c|}{ Miejscowość - Location* } & \multirow{2}{*}{$\begin{array}{c}\text { Średnia } \\
\text { Mean }\end{array}$} \\
\hline & $\mathrm{A}$ & $\mathrm{B}$ & $\mathrm{C}$ & $\mathrm{D}$ & $E$ & $\mathrm{~F}$ & $\mathrm{G}$ & $\mathrm{H}$ & I & $\mathrm{J}$ & $\mathrm{K}$ & $\mathrm{L}$ & \\
\hline Baryt & 16,5 & 39,1 & 22,7 & 22,1 & 21,9 & 21,2 & 11,3 & 20,5 & 27,5 & 19,1 & 20,1 & 19,7 & 21,8 \\
\hline Dukat & 16,1 & 32,8 & 20,6 & 22,4 & 19,4 & 20,0 & 15,0 & 15,8 & 26,2 & 14,5 & 16,8 & 17,8 & 19,8 \\
\hline Lord & 15,3 & 31,5 & 20,9 & 21,4 & 19,4 & 19,4 & 15,1 & 14,2 & 26,7 & 13,9 & 16,7 & 18,4 & 19,4 \\
\hline Mister & 16,9 & 32,6 & 22,7 & 21,3 & 20,6 & 20,4 & 15,5 & 12,8 & 27,0 & 13,7 & 15,7 & 19,2 & 19,9 \\
\hline Parys & 9,3 & 26,5 & 13,9 & 11,0 & 10,6 & 15,0 & 8,0 & 15,6 & 16,4 & 7,4 & 11,3 & 7,8 & 12,7 \\
\hline Perkoz & 13,1 & 31,8 & 20,1 & 19,9 & 17,2 & 16,7 & 15,6 & 13,9 & 23,5 & 13,1 & 14,5 & 17,4 & 18,1 \\
\hline Talar & 16,9 & 34,0 & 23,1 & 19,7 & 18,4 & 19,1 & 14,6 & 15,6 & 25,3 & 13,9 & 16,6 & 18,0 & 19,6 \\
\hline Taper & 12,8 & 30,3 & 20,3 & 18,2 & 16,2 & 16,7 & 10,8 & 12,7 & 21,5 & 13,1 & 14,1 & 15,6 & 16,9 \\
\hline $\begin{array}{l}\text { Średnia } \\
\text { Mean }\end{array}$ & 14,6 & 32,3 & 20,5 & 19,5 & 18,0 & 18,6 & 13,2 & 15,2 & 24,3 & 13,6 & 15,7 & 16,7 & 18,5 \\
\hline $\begin{array}{l}\text { NIR }(0,05) \\
\operatorname{LSD}(0.05)\end{array}$ & 1,24 & 2,16 & 2,08 & 1,84 & 1,66 & 1,92 & 0,98 & 2,81 & 2,44 & 1,56 & 2,38 & 1,75 & 2,24 \\
\hline
\end{tabular}

*A - Białogard, B - Bobrowniki, C - Cicibór Duży, D - Głodowo, E - Marianowo, F - Nowa Wieś Ujska, G - Nowy Lubliniec, H - Ruska Wieś, I - Sulejów, J - Świebodzin, K - Tomaszów Bolesławiecki, L - Uhnin 
Tabela 4. Masa 1000 nasion łubinu żółtego w latach (2010-2012) [g]

Table 4. Weight of 1000 seeds of yellow lupine in the years 2010-2012 [g]

\begin{tabular}{|c|c|c|c|c|c|c|c|c|c|c|c|c|c|}
\hline \multirow{2}{*}{$\begin{array}{l}\text { Odmiana } \\
\text { Cultivar }\end{array}$} & \multicolumn{12}{|c|}{ Miejscowość - Location* } & \multirow{2}{*}{$\begin{array}{c}\text { Średnia } \\
\text { Mean }\end{array}$} \\
\hline & A & B & $\mathrm{C}$ & $\mathrm{D}$ & $\mathrm{E}$ & $\mathrm{F}$ & $\mathrm{G}$ & $\mathrm{H}$ & I & $\mathrm{J}$ & $\mathrm{K}$ & $\mathrm{L}$ & \\
\hline Baryt & 164 & 146 & 130 & 133 & 137 & 126 & 117 & 141 & 128 & 128 & 130 & 121 & 133 \\
\hline Dukat & 146 & 135 & 125 & 130 & 132 & 126 & 135 & 138 & 122 & 123 & 129 & 122 & 130 \\
\hline Lord & 145 & 133 & 125 & 127 & 136 & 125 & 126 & 130 & 120 & 122 & 126 & 119 & 128 \\
\hline Mister & 156 & 142 & 139 & 138 & 143 & 137 & 138 & 142 & 134 & 129 & 132 & 134 & 139 \\
\hline Parys & 157 & 143 & 120 & 134 & 158 & 132 & 130 & 134 & 136 & 129 & 133 & 157 & 138 \\
\hline Perkoz & 152 & 140 & 131 & 133 & 130 & 141 & 131 & 138 & 133 & 126 & 142 & 130 & 136 \\
\hline Talar & 117 & 141 & 132 & 131 & 141 & 127 & 133 & 141 & 123 & 127 & 131 & 123 & 131 \\
\hline Taper & 146 & 133 & 128 & 131 & 127 & 131 & 121 & 141 & 128 & 120 & 134 & 118 & 130 \\
\hline $\begin{array}{l}\text { Średnia } \\
\text { Mean }\end{array}$ & 148 & 139 & 130 & 132 & 135 & 130 & 129 & 139 & 127 & 125 & 132 & 124 & 133 \\
\hline $\begin{array}{l}\text { NIR }(0,05) \\
\text { LSD }(0.05)\end{array}$ & 8,12 & 6,24 & 3,76 & 4,18 & 4,04 & 5,10 & 6,14 & 3,24 & 3,17 & 3,36 & 4,12 & 5,66 & 3,42 \\
\hline
\end{tabular}

*A - Białogard, B - Bobrowniki, C - Cicibór Duży, D - Głodowo, E - Marianowo, F - Nowa Wieś Ujska, G - Nowy Lubliniec,

H - Ruska Wieś, I - Sulejów, J - Świebodzin, K - Tomaszów Bolesławiecki, L - Uhnin

było znikome, co wynikało najprawdopodobniej z tego, że stopień porażenia roślin łubinu w latach badań nie był na tyle duży, aby istotnie oddziaływać na wielkość uzyskiwanych plonów nasion. Z doniesień literatury wynika jednak, że występujące na plantacjach łubinu choroby mogą powodować wyraźne pogorszenie wielkości i jakości plonu nasion łubinu (Horoszkiewicz i Filoda 2001). Zaleca się ich zwalczanie, stosując odpowiednią ochronę chemiczną. Obecnie nie ma fungicydów do zwalczania chorób łubinu żółtego (Horoszkiewicz-Janka i wsp. 2013), co stanowi duży problem w uprawie tego gatunku.

Średnio dla 3 lat badań i wszystkich miejscowości większość uwzględnionych $\mathrm{w}$ badaniach odmian łubinu plonowała na podobnym poziomie, tj. 16,9-19,8 dt/ha. Najlepiej, niezależnie od rejonu uprawy, plonował łubin odmiany Baryt (21,8 dt/ha), a najsłabiej łubin odmiany Parys (12,7 dt/ha).

Nie stwierdzono wyraźnej zależności pomiędzy masą 1000 nasion (tab. 4) a wielkością uzyskiwanego plonu. Jedynie w przypadku miejscowości Białogard, gdzie uzyskano najwyższe plony nasion łubinu (32,3 dt/ha) stwierdzono również największą masę pojedynczego nasienia. Z kolei w miejscowości Ruska Wieś uzyskano nasiona o stosunkowo dużej masie 1000 nasion, a plon był jednym $\mathrm{z}$ najniższych spośród uzyskanych w poszczególnych rejonach prowadzenia badań $(15,1 \mathrm{dt} / \mathrm{ha})$. Cechą decydującą $\mathrm{w}$ największym stopniu o plonowaniu łubinu żółtego jest liczba strąków na roślinie (Podleśny 2007; Podleśny i Strobel 2007), jednak nie była oceniana w tych badaniach.

\section{Wnioski / Conclusions}

1. We wszystkich latach badań obserwowano porażenie roślin przez grzyby chorobotwórcze, a nasilenie wystę- powania chorób zależało w znacznym stopniu od rejonu uprawy łubinu. Spośród stwierdzonych chorób dominowała antraknoza, występująca w rejonach Polski z dużą ilością opadów i wysoką temperaturą w okresie kwitnienia łubinu oraz pojawiające się lokalnie w warunkach małej ilości opadów i wysokiej temperatury - fuzaryjne więdnięcie łubinu.

2. W obrębie uwzględnionych $\mathrm{w}$ badaniach odmian łubinu żółtego nie ma zbyt wielu takich, które wykazywałyby zdecydowanie większą od pozostałych odporność na wszystkie analizowane patogeny chorobotwórcze. Jedynie odmiana Mister była nieco mniej porażana przez $F$. oxysporum, odmiana Parys przez $P$. setosa oraz odmiana Taper przez $C$. gloeosporioides.

3. Stwierdzono duże różnice w plonowaniu łubinu żółtego pomiędzy rejonami jego uprawy. Średnio dla 3 lat badań, najwyższe plony nasion tego gatunku uzyskano w miejscowościach: Bobrowniki, Cicibór Duży i Sulejów, a najniższe w miejscowościach Nowy Lubliniec i Świebodzin.

4. Większość uwzględnionych w badaniach odmian Łubinu plonowała na podobnym poziomie. Najlepiej, niezależnie od rejonu uprawy, plonował łubin odmiany Baryt, a najsłabiej łubin odmiany Parys.

Praca wykonana w ramach realizacji zadania 3.3 w Programie Wieloletnim Instytutu Uprawy Nawożenia i Gleboznawstwa - Państwowego Instytutu Badawczego w Puławach „Wspieranie działań w zakresie kształtowania środowiska rolniczego i zrównoważonego rozwoju produkcji rolniczej w Polsce". 


\section{Literatura / References}

Domański P.J., Osiecka A., Paczocha J. 2013. Lista opisowa odmian. Rośliny rolnicze. Łubin wąskolistny. COBORU, Słupia Wielka: 131-143.

Dubis B., Budzyński W. 1998. Wartość przedplonowa różnych typów łubinu żółtego dla zbóż ozimych. Rocz. Nauk Rol., Seria A, 113 (3-4): 145-154.

Frencel I. 1999. Postępy badań nad antraknozą łubinów (Glomerella cingulata/Colletotrichum gloeosporioides) w Polsce i Europie. s. 199-206. W: Mat. Konf. „Lupin in Polish and European Agriculture”. PTŁ, Przysiek, 2-3 wrzesień 1999, 257 ss.

Frencel I. 2000. Kierunki i perspektywy hodowli odpornościowej łubinów na antraknozę w świetle aktualnych badań. s. 20-31. W: Mat. Konf. „Obecny stan i kierunki badań nad łubinem w Polsce ze szczególnym uwzględnieniem antraknozy”. Inst Ochr. Roślin, Poznań, 12 styczeń 2000, 48 ss.

Filoda G., Horoszkiewicz J., Jańczak C. 2001. Występowanie i szkodliwość antraknozy na łubinie żółtym w różnych warunkach pogodowych 1999 i 2000 roku. [Occurence and pathogenity of yellow lupin anthracnose in different weather conditions in 1999 and 2000]. Prog. Plant Prot./Post. Ochr. Roślin 41 (1): 278-285.

Horoszkiewicz J., Fiolda G. 2001. Choroby grzybowe łubinu żółtego i wąskolistnego. Zesz. Nauk. AR Wrocław, Rolnictwo 427: $185-193$.

Horoszkiewicz-Janka J., Jajor E., Korbas M. 2013. Zagrożenie roślin strączkowych (bobowych) przez grzyby chorobotwórcze i możliwości ich zwalczania. [Potential risk of infection of pathogenic fungi to legumes (Fabales) and possibilities of their control]. Prog. Plant Prot./Post. Ochr. Roślin 53 (4): 762-767.

Jańczak C., Filoda G., Horoszkiewicz-Janka J. 2003. Antraknoza łubinu w Polsce w latach 1999-2002, zwalczanie i skuteczność działania środków grzybobójczych. Zesz. Probl. Post. Nauk Rol. 195: 251-260.

Jasińska Z., Kotecki A. 1993. Rośliny strączkowe. PWN, Warszawa, 206 ss.

Osiecka A., Wiatr K. 2010. Lista opisowa odmian. COBORU, Słupia Wielka: 94-104.

Podleśny J. 2007. Dynamika gromadzenia suchej masy i plonowanie termoneutralnych i nietermoneutralnych odmian łubinu żółtego w zależności od terminu siewu. Zesz. Probl. Post. Nauk Rol. 522: 297-306.

Podleśny J., Brzóska F. 2010. Uprawa łubinu żółtego i wykorzystanie nasion w żywieniu zwierząt. Instrukcja Upowszechnieniowa 173, 34 ss.

Podleśny J., Podleśna A. 2011. Effect of rainfall amount and distribution on growth, development and yields of determinate and indeterminate cultivars of blue lupin. Polish J. Agron. 4: 16-22.

Podleśny A., Podleśna A. 2012. Wpływ wysokiej temperatury w okresie kwitnienia na wzrost, rozwój i plonowanie łubinu żółtego. Acta Agrophys. 19 (4): 825-834.

Podleśny J., Strobel W. 2007. Wpływ typu odmiany i terminu siewu na plon i skład aminokwasowy białka nasion łubinu żółtego. Acta Agrophys. 151, 10 (1): 175-185.

Prusiński J., Kaszkowiak E., Borowska M. 2008. Wpływ nawożenia i dokarmiania roślin azotem na plonowanie i strukturalne elementy plonu nasion bobiku. Fragm. Agron. 25 (4): 111-127.

Sowa A., Sadowski Cz. 1979. Występowanie zgorzeli korzeni grochu (Pisum sativum L.) na plantacjach w województwie bydgoskim. Zesz. Nauk. AT-R Bydgoszcz 76 (8): 49-63.

Zalewski D., Janiszewska I., Janiszewska K., Kotowicz Z., Wójcik B., Śmiałek E. 2003. Ocena podatności odmian łubinu żółtego (Lupinus luteus L.) na Fusarium spp. w zależności od warunków klimatyczno-glebowych. Zesz. Probl. Post. Nauk Rol. 495: 307-314. 